\title{
Sulfurization of Trivalent Phosphorus Compounds with 1,2-Dithiole-3-thione ${ }^{\dagger}$
}

\author{
Józef Drabowicz, Jerzy Luczak, Piotr Łỳzwa, Marian Mikolajczyk, and Carl Th. Pedersen ${ }^{\ddagger}$ \\ Centre of Molectlar and Hacromolecular. Studies, Polish Academ of Sciences, \\ Department of Heteroorganic Chemistry, 90-363 Lódź, Sienkiewicza 112, Poland \\ -Department of Chemistry Odense Lniversity, DK-5230 Odense $\mathrm{H}_{1}$ Denmark \\ Received Mav 18, 2004
}

Key Words : Sulfurization. Phosphine sulfide. Thionophosphate, Thione

\begin{abstract}
A few methods have been utilized for the preparation of tertiary phosphine sulfides. $\mathrm{R}_{3} \mathrm{P}=\mathrm{S}{ }^{1}$ These include the reaction of organometallic reagents with halides of phosphorus thioacids. ${ }^{2}$ the Fridel-Crafts reaction between thiophosphonyl (thiophosphoryl or thiophosphinic) chlorides and arenes ${ }^{3}$ or between phosphorus trichloride and benzene in the presence of elemental sulfur. ${ }^{4}$ The most convenient preparation of such phosphine sulfides constitutes still the direct sulfurization of the parent phosphines. Here again a few reagents have been applied including elemental sulfur. ${ }^{5}$ sodium polysulfides ${ }^{6}$ and cyclic organic sulfides. ${ }^{7}$ Similarly. the addition of elemental sulfur to phosphites (or other trivalent analogues) constitutes the most common procedure for the preparation of the corresponding thionophosphates (or other thionoanalogues).

Earlier. one of us has reported ${ }^{8}$ that the reaction of 1.2dithiolane-3-thione 1 with tripheny phosphine 2a afforded (beside the $\left[\mathrm{C}_{3} \mathrm{H}_{2} \mathrm{~S}_{2}\right]_{n}$ polymer terminated by $\mathrm{Ph}_{3} \mathrm{P}$ substituent3) almost quantitative yield of the corresponding triphenylphosphine sulfide $4 a(E q .1)$. This observation indicates a possibility of the use of the thione 1 as an alternative sulfurization agent for trivalent organophosphonus compounds.
\end{abstract}

$$
\underbrace{\stackrel{\mathrm{S}}{\mathrm{S}}+\mathrm{Ar}_{3} \mathrm{P} \underset{\text { toluene }}{\stackrel{\Delta}{\longrightarrow}}\left[\mathrm{Cr}_{3} \mathrm{H}_{2} \mathrm{~S}_{2}\right]_{13} \mathrm{PPh}_{3}+\mathrm{Ar}_{3} \mathrm{P}=\mathrm{S}}_{\mathbf{S}}
$$

In this context, it is interesting to note that in the chemical literature one can find only two papers describing the thionation type of the reaction between phosphorus compound and a thiocarbonyl component. The first paper reported ${ }^{9}$ that the reaction of 4,5-dicyano-1,3-dithiole-2thione $\mathbf{5}$ with tri-n-butylphosphine $\mathbf{2 b}$ gave a mixture of products, one of which was identified as tri- $n$-butylphosphine sulfide $+\mathbf{b}$ (Eq. 2).

Dedicated to Prof. Yong Hae Kim on the occasion of his retirement from the Korean Advanced Institute of Science and Technology [KAIST] "Corresponding Author: e-11nail: draj $c$ bilbo.cbmm.lodz.pl

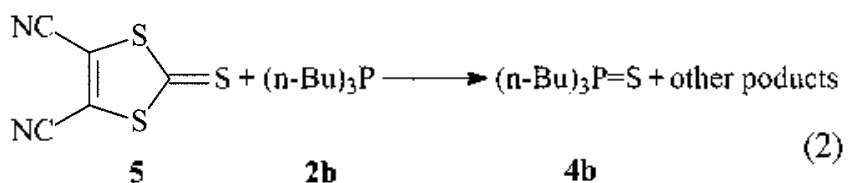

The second one described ${ }^{15}$ the high temperature $\left(100^{\circ} \mathrm{C}\right)$ reaction of tri- $\eta$-butylphosphine $\mathbf{2 b}$ with thiobenzophenone 6 which gave mainly tri- 7 -butylphosphine sulfide th $(89 \%)$. 1.1,2.2-tetraphenylethane $7(65 \%)$ and tetraphenylethylene $(28 \%)(\mathrm{Eq} .3)$. The intermediacy of carbene in the reaction was suggested.

$$
\begin{aligned}
& \mathrm{Ph}_{2} \mathrm{C}=\mathrm{S}+(\mathrm{n}-\mathrm{Bu})_{3} \mathrm{P} \longrightarrow(\mathrm{n}-\mathrm{Bu})_{3} \mathrm{P}=\mathrm{S}+\left(\mathrm{Ph}_{2} \mathrm{CH}\right)_{2}+\mathrm{Ph}_{2} \mathrm{C}=\mathrm{CPh}_{2} \\
& \begin{array}{lllll}
6 & 2 b & 4 b & 7 & 8
\end{array}
\end{aligned}
$$

\section{Results and Discussion}

To show a possibility of application of the thione 1 as a new sulfurizating reagent we have started our experiments with a few trialkyl phosphites 9 . We were glad to find that in this case sulfurization reaction is rapid and very clean giving at room temperature the corresponding thionophosphates 10 as a single reaction product ( ${ }^{31} \mathrm{P}-\mathrm{NMR}$ assay) (Eq. 4). On the other hand. under the same reaction conditions triphenylphosplite $9 \mathrm{~d}(\mathrm{R}=\mathrm{Ph})$ gave a complex mixture of phosphoruscontaining products.

$$
\left(\begin{array}{c}
(\mathrm{RO})_{3} \mathrm{P} \\
9
\end{array}\right.
$$

In a sharp contrast to this when a few aromatic and aliphatic tertiary phosphines $\mathbf{2 a - g}$ were allowed to react with the thione 1 in boiling benzene for a few hours the corresponding phosphine sulfides $4 \mathrm{a}-\mathrm{g}$ were formed cleanly although always accompanied by the traces of the corresponding phosphine oxides ( ${ }^{3}$ P-NMR assay). They were isolated in a very high yield (Table 1) by a standard colunn chromatography of a crude reaction product.

If the reaction of $\mathrm{P}^{\mathrm{III}}$ compounds with 1.2-dithiole-3- 
Table 1. Sulfurization of triaryl(alkyl)phosphines 2 with 1,2-Dithiole-3-thione-1

\begin{tabular}{|c|c|c|c|c|c|c|c|}
\hline & & \multicolumn{6}{|c|}{ Product } \\
\hline \multicolumn{2}{|c|}{ Substrate } & & & \multirow[t]{2}{*}{ Yield $[\%]^{a}$} & \multicolumn{2}{|r|}{$\mathrm{Mp}\left[{ }^{\mathrm{J}} \mathrm{C}\right]$} & ${ }^{3} \mathrm{P}-\mathrm{NMR}$ \\
\hline No & $\mathrm{R}$ & No & $\mathrm{R}$ & & found & reported & $\delta$ [ppml $]$ \\
\hline $2 a$ & $\mathrm{Ph}$ & ta & $\mathrm{Ph}$ & 83 & $158-160$ & $157-158^{6}$ & +43.0 \\
\hline $2 b$ & $n$-Bu & $4 b$ & $n-\mathrm{Bu}$ & 86 & oil & $134-136 / 0 \mathrm{mmHg}^{17}$ & +47.5 \\
\hline $2 c$ & $p$-Tol & $4 c$ & $p$-Tol & 87 & $181-183$ & $185-186^{0.18}$ & +41.1 \\
\hline $2 d$ & $p-\mathrm{Cl}-\mathrm{C}_{6} \mathrm{H}_{4}$ & $4 d$ & $p-\mathrm{Cl}-\mathrm{C}_{5} \mathrm{H}_{4}$ & 83 & $149-151$ & $152-153^{10}$ & +40.2 \\
\hline $2 \mathrm{e}$ & $p-\mathrm{F}-\mathrm{C}_{6} \mathrm{H}_{4}$ & te & $p-\mathrm{F}-\mathrm{C}_{6} \mathrm{H}_{4}$ & 86 & $137-138$ & $139-141^{281}$ & +41.0 \\
\hline $2 f$ & $p-\mathrm{MeO}-\mathrm{C}_{6} \mathrm{H}_{4}$ & $4 f$ & $p-\mathrm{MeO}-\mathrm{C}_{6} \mathrm{H}_{4}$ & 90 & $107-110$ & $109-110^{18}$ & +41.0 \\
\hline
\end{tabular}

"isolated after column chromatography

thione 1 were found to be stereospecific, this thione would be the preferred reagent for thionation of chiral phosplines. With this in mind we have exanined thionation of optically active $(+)-(S)$-methyl-n-propylphenyl phosphine $11^{11}$ and found that it resulted in the formation of the corresponding $(+)-(R)$-phosphine sulfide $12^{12}$ with stereoselectivity close to $70 \%$ and with retention of configuration at phosphorus (Eq. 5).

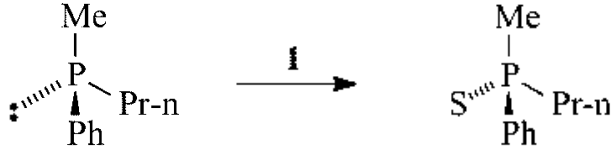

$$
\begin{aligned}
& (+)-(S)-11
\end{aligned}
$$

On the other hand, the reaction between the levorotatory phosphine oxide $(-)-(S)-13^{13}$ and the thione 1 gave after 33 days at room temperature the dextrorotatory enantiomer of $t$ butylphenylphosphinothioic acid $(+)-(R)-14^{14}$ with full retention of configuration at the stereogenic phosphorus atom (Eq. 6). However, a few unindentified phosphoruscontaining products having chemical shifts around $+70 \mathrm{ppm}$ were observed in a crude reaction mixture $\left({ }^{31} \mathrm{P}-\mathrm{NMR}\right.$ assay $)$.<smiles>O=[PH](Br)c1ccccc1</smiles>

$$
(-)-(S)-13 \quad(+)-(R)-14
$$

$[\alpha]_{589}=-32.5\left(\mathrm{CHCl}_{3}\right)[\alpha]_{589}=+26.4(\mathrm{MeOH})$

$$
\text { ee }=88.4 \% \quad \text { ee }=88.4 \%
$$

Retention at phosphorus observed in the above mentioned thionation reactions may be easily explained by the mechanistic sequence proposed in Scheme 1. It is reasonable to assume that the first step of the reaction between phosphines 2 or the trivalent tautomer of the phosphine oxide 13 and 1 is the nucleophilic attack of phosphorus at the 5-position of the thione as this position easily undergoes nucleophilic attack. This results in the formation of the "Zwitterion" 15. It may then undergo intemal opening to give subsequently the structures 16 and 17 which upon cyclization forms the intermediate phosphorane 18. in which
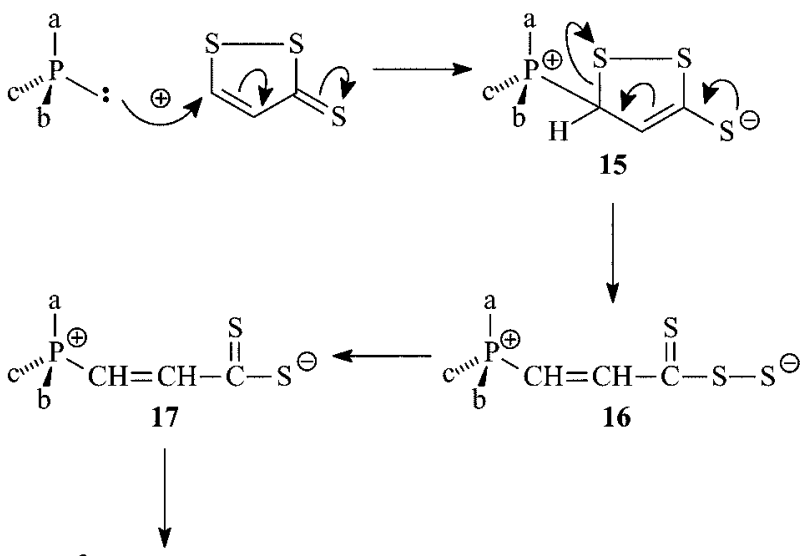

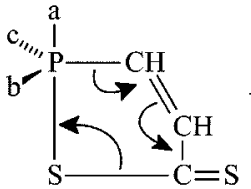

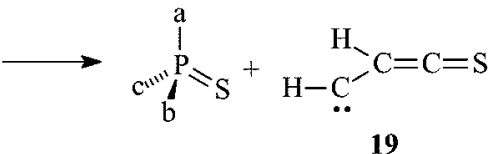

18<smiles>C=c1sc(=CC=Cc2cc3sc2s3)s1</smiles>

20

Scheme 1

the five membered ring spans axial and equatorial positions. Such a structure should be the most convenient from the point of view of apicophilicity of substituents at phosphons in trigonal-bipyramidal species. ${ }^{15}$ Decomposition of the fivecoordinate intermediate 18 gives the phosphine sulfide with retention of configuration at phosphorus and the carbene intermediate 19 from which polymer 20 could possibly be formed. $^{8}$ This proposal is in full agreement with the experimental observation that a black polymeric precipitate was always formed during the discussed thionation reaction.

\section{Experimental Section}

General. Melting points which are uncorrected were 
deternined in capillary tubes. ${ }^{31} \mathrm{P}$ NMR spectra were obtained on a Burker $200 \mathrm{MHz}$ and JOEL $400 \mathrm{MHz}$ spectrometer and the ${ }^{31} \mathrm{P}$ chemical shifts are reported as referenced to the external $85 \% \quad \mathrm{H}_{3} \mathrm{PO}_{4}$ with resonance deshielded from the reference as being reported as positive. Thin layer cluromatogranı for analytical purposes were run on alumina plates coated with a layer of silica gel $\mathrm{GF}_{2 \leq 4}$ (Merck). Colunu chromatograply was done on silica gel (Merck. 60-200 mesh). Optical activity measurements were made with a Perkin-Elmer 241 MC photopolarinienter: concentrations of the solutions were about $1-2 \mathrm{~g} / 100 \mathrm{~mL}$.

Materials. All starting trialkyl(aryl) phosphates and triarylphosplines were conmercially available products. 1.3-Dithiole-3-thione. ${ }^{16}(+)$-(S)-methyl-n-propylphenylphosphine $^{1]}$ and (-)-(S)-t-butylphenylphosphine oxide 13a were prepared according to the established procedure.

Reaction of 1,2-Dithiole-3-thione with Triarylphosphines. A solution of 1,3-dithiole-3-thione $(0.536 \mathrm{~g}$. 0.004 mol) and triarylphosphine $2(0.004 \mathrm{~mol})$ in $50 \mathrm{~mL}$ of dry benzene was refluxed and the reaction progress was monitored by TLC. After cooling. the black precipitate was filtered and washed with $50 \mathrm{~mL}$ of ether and $30 \mathrm{~mL}$ of benzene. Evaporation of the benzene and the solvent used to wash the precipitate gave brownish crystals. which were crude triarylphosphine sulfides. The crude phosphine sulfides were funally purified by columu chromatography to give virtually pure products listed in Table 1.

Conversion of (+)-(S)-Methylphenyl-n-propylphosphine-11 to $(+)-(R)$-Phosphine Sulfide-12 by Means of 1,2-Dithiole-3-thione-1. A solution of 11 [ $448 \mathrm{mg}(0.00024$ $\mathrm{mol}$ ), $[\alpha]_{\mathrm{s}}=+18.3$ (toluene), ee $\left.=93.5 \%\right]$ and $1[19 \mathrm{mg}$ $(0.00019 \mathrm{~mol})]$ in benzene $(2 \mathrm{~mL})$ was stirred at room temperature for $0.5 \mathrm{hrs}$. After this time a black precipitate was filtered and washed with diethyl ether $(3 \times 20 \mathrm{~mL})$. The organic phase was washed in a row with $5 \%$ aqueous solutions of $\mathrm{H}_{2} \mathrm{SO}_{4} .5 \%$ aqueous solution of $\mathrm{K}_{3} \mathrm{CO}_{3}$ and water and dried over dry $\mathrm{MgSO}_{4}$. Evaporation of the solvent afforded a solid (39.8 $\mathrm{mg} 92 \%$ ) which was purified by preparative TLC chromatographỵ [ethỵl ether-petroleum ether $(1: 1)$ as an eluent] to give virtually pure $(+)-(\mathrm{R})$ methylpheny'l-n-propylphosphine sulfide $12[21.8 \mathrm{mg}$ $(0.00011 \mathrm{~mol}),(46 \%),[\alpha]_{589}=+14.4(1.09 \mathrm{MeOH})$, ee $=$ $\left.63.4 \% . \delta_{31 \mathrm{~F}}=+41.48(\mathrm{MeOH})\right]$.

Conversion of $(-)-(S)-t$-Butylphenylphophine Oxide-13 to $(+)-(R)-t$-Butylphenylthiophosphinic acid-1 4 by Means of 1,2-Dithiole-3-thione-1. A solution of $13[0.184 \mathrm{~g}(0.00]$ mol),$[\alpha]_{5 s 9}=-32.5\left(1.53 \mathrm{CHCl}_{3}\right)$. ee $\left.=88.4 \%\right]$ and $1[80 \mathrm{mg}$ $(0.0006 \mathrm{~mol})]$ in $\mathrm{CDCl}_{\hat{\jmath}}(2 \mathrm{~mL})$ was kept in a NMR tube at room temperature for 33 days and the reaction progress was followed by the ${ }^{31} \mathrm{P}$ NMR. After this time the black precipitate was filtered and washed with dietlyl ether $(3 \times 20$ $\mathrm{mL}$ ). Evaporation of the $\mathrm{CDCl}_{3}$ and the solvent used to wash the precipitate afforded a solid which was purified by columu chromatography [ethyl ether-petroleum ether $(1: 1)$ as an eluent] to give $(+)-(R)$-t-butylphenylphosphinothioic acid $14\left[0.092 \mathrm{~g}(48 \%) .[\alpha]_{589}=+26.4(1.06 \mathrm{MeOH})\right.$. ee $=$ $\left.88.4 \%, \delta_{31 \mathrm{P}}=+98.6\left(\mathrm{CDCl}_{3}\right)\right]$

Acknowledgements. Studies in Lodz were partially supported by the State Committee for Scientific Research (KBN-grant 4T09A 10522 to J.D.)

\section{References}

1. (a) Hevdt, H; Regitz, M. In Methoden der Organischen Cheme? (Houben-Weyl); Ed. Regitz, M., Ed.; Georg Thieme verlag: Stuttart-New York. 1982: Vol. E-2. pp 77-92.

2. (a) Screttas. C.: Isbell. A. F. J. Org. Chent 1963. 27. 2573. (b) Harwood. H. J.: Pollart. K. A. J. Org. Chem. 1963. 28. 3430. (c) Maier. L. Hel. Chm Acta, Chem. Bet 1961. 94, 3043

3. Maier. L. Het Chim Acta. Chem Ber: 1964, $47,120$.

4. Olah. G. A.: Hehemann. D. J. Org. Chem. 1977, 42. 2190.

5. Maier. L. In Topics in Phosphorus Chemisty: Gayson. M.. Griftith. E. I.. Eds.: Intrascience: New York. 1965: Vol. 2. p 43.

6. Miranda. R.: Salas. I.: Mondragon. T.: Valasco. L. Symthetic Contmin. 1992. 22, 1077.

7. Young. D. P.: McEwen. W. E.: Valez. D. C.: Johnson. J. W: Vander Werf, C. A. Tetrahedron Lett. 1964. 359.

8. Pedersen. C. Th. Sulfur Lett. 1997. 20.179.

9. Miles. M. M.: Wager. J. S.: Wilsont. T. D.: Siedle. A. R. J. Org. Chent 1975. 40.2577 .

10. Ogata. Y.: Yamashita. M.: Mizutani, M. Bull. Chent. Soc. Jpn. 1976. 19,1721 .

11. (a) Horner. L.: Balzer, W. D. Tetrahedron Lett. 1965. 1175 . (b) Zon1. G.: De Bruin. K. E.: Naumantr. K.: Mislow. K. J. Am. Chem. Soc. 1969.91 .7023$.

12. (a) Horner. L. Pute Appl. Chem. 1964. 9. 225. (b) Zon. G.: Mislow. K. Top. Cum Chent 1971, 19,61.

13. (a) Drabowicz. J.: E.y.wa, P.: Omelańczuk, J.: Pietrusiewicz, K. M.: Mikołajczyk. M. Tetrahedron: Asymmetry 1999. 10,2757. (b) Wang. F.: Polavarapu. P. L.: Drabowicz. T.: Mikolajczyk. M. $J$. Org. Chem. 200. 65.7561.

14. (a) Michalski. T.: Skizypezy ński. Z. J. Organontet. Chem. 1975. 97, C31. (b) Wang. F.: Polavarapu. P. L.: Drabowicz, J.; Mikołajeztk: M. J. Org. Chen 2001, 66,9015.

15. Trippett. S. Phosphorus Sulfur 1976, 1.89.

16. Meinetsberger. E.: Schöffer. A.: Behringer. H. Synthesis 1961. 802

17. Sherry. A. D.: Purcell. K. F. J. Am. Chent. Soc. 1972. 94. 1848.

18. Ballah. V: Subbarayan, P. J. Org. Chem. 1960. 25. 1833.

19. Schimenz. G. P. Chem. Ber: 1966.99 .504

20. Schindlbauer, H. Chem.Ber: 1967. 100, 3432 